\title{
INFLUENCE OF DIETARY SUPPLEMENTATION OF PROPOLIS ON PRODUCTIVE PERFORMANCE, IMMUNOLOGICAL AND PHYSIOLOGICAL PARAMETERS OF GROWING JAPANESE QUAIL
}

\author{
W. M. Dosoky ${ }^{1}$, H .Zeweil ${ }^{1}$ and Soha A. Farag ${ }^{2}$ \\ 1- Department of Animal and Fish Production, Faculty of Agriculture (Saba Basha), Alexandria University, \\ Alexandria, Egypt, 2- Department of Animal Production, Faculty of Agriculture, Tanta University, Tanta, Egypt
}

\section{SUMMARY}

This study was designed to determine the effect of different levels of propolis on growth parameters, blood constituents, immunity and anti-oxidative properties of growing Japanese quail (Coturnix coturnix Japonica). Propolis was added to the basal diet at five different levels being 0, 75, 150, 225, and $300 \mathrm{mg} / \mathrm{kg} \mathrm{diet}$, respectively. Quail fed diets containing 75, 150, 225 and $300 \mathrm{mg}$ propolis/kg diet had significantly heavier body weights than those fed control diet throughout the experimental period. Feed intake increased gradually by increasing propolis levels in the diets compared with the control group. Significant improvement in feed conversion ratio was noticed only in quail fed $300 \mathrm{mg}$ propolis $/ \mathrm{kg}$.

Relative weight of bursa and thymus were significantly $(\mathrm{P} \leq 0.01)$ increased in quail fed $300 \mathrm{mg}$ propolis. Serum total protein and globulin content of propolis treatment were significantly higher than control $(\mathrm{p} \leq 0.05)$. Serum aspartete aminotransferese significantly $(\mathrm{P} \leq 0.05)$ affected by different treatments. Serum total lipids, cholesterol, high density lipoprotein and triglycerides were decreased significantly $(\mathrm{P} \leq 0.01)$ with inclusion of different levels of propolis. Serum glutathione peroxidase activity was significantly $(\mathrm{P} \leq 0.01)$ increased in the groups had $300 \mathrm{mg}$ propolis as compared to the control group. Serum total antioxidant capacity was significantly $(\mathrm{P} \leq 0.01)$ increased in the groups had 225 and $300 \mathrm{mg}$ propolis as compared to other groups, while serum lipid peroxide concentration was significantly $(\mathrm{P} \leq 0.001)$ decreased by increasing propolis levels in the diets, except the group had $75 \mathrm{mg}$ propolis was significantly equal to the control group.

Antibody titers against Newcastle disease were significantly $(\mathrm{P} \leq 0.001)$ higher in all propolis groups as compared to control group at 14 and 21days post-vaccination. In histometrical examination proved that propolis at 150 and $300 \mathrm{mg} / \mathrm{kg}$ diet improve follicular size in bursa and follicular cortex in thymus. In conclusion, inclusion of propolis in growing quail diets may exert beneficial effects on growth parameters, blood constituents, immunity and anti-oxidative properties.

Keywords: Propolis, growth performance, blood, antioxidative properties, immune response and Japanese quail

\section{INTRODUCTION}

It is well known that, feed additives can be used safely in poultry ration to improve their performance. Currently, world attentions are directed to the traditional medicine (Elmahdi et al., 2014). Propolis is one of the hive products produced by the worker bees who apply the resin to seal any cracks and fissures in the hive and they line their front door with it to prevent contamination (Popova et al., 2013). They use it as an antiseptic in breeder cells and they mix propolis with wax to distribute a fine varnish over every inch of the hive to protect it (Burdock, 1998).The chemical consistency of propolis is highly dependent on the flora of the region from where it is collected (Banskota et al., 2001 and Osman and Taha, 2008). However, caffeic acid phenethyl ester is the active component of propolis (Song et al., 2002). Propolis contains $50-70 \%$ resins and $10 \%$ essential oils, coming from the trees, mixed with $30-50 \%$ wax for proper consistency and 5-10\% pollen, acquired from being transported in the bees's pollen baskets. Propolis has been used extensively in folk medicine, due to its several pharmacological and biological properties such as antimicrobial, immunomodulatory, anti inflammatory, and antioxidant (Shawky, 1996; Amal, 1997; Abd El-Fattah et al., 1999; Osman and
Taha, 2008; Nakamura et al., 2010 and Vatansever et al., 2010).

Therefore, this study was designed to test the impacts of different levels of propolis on performance, blood constituents, immunity and antioxidative properties of growing Japanese quail.

\section{MATERIALS AND METHODS}

This study was carried out at the Poultry Research laboratory belonging to Faculty of Agriculture (Saba Basha), Alexandria University. Alexandria, Egypt.

One hundred and fifty-7 day old unsexed Japanese quail chicks were used in this experiment. Chicks were divided randomly into five groups with thirty chicks in each group and each group was allotted into three replicates (10 birds in each) in a complete randomized design. Propolis was added to the basal diet at five different levels being $0,75,150,225$, and $300 \mathrm{mg}$ propolis $/ \mathrm{kg}$ diet, respectively. Treatments were applied for 5 weeks. Propolis obtained as powder from Egyptian market (HNBOOMBP- 01, code: 410004900, Henan Boom, China). The composition and chemical analyses of the experimental basal diets were formulated according to NRC (1994) and presented in Table (1). 
Table 1. Composition and calculated analysis of the experimental diets

\begin{tabular}{lc}
\hline Ingredients & $(\%)$ \\
\hline Yellow corn & 57.25 \\
Soybean meal $(44 \%)$ & 31.7 \\
Broiler concentrate (52\%) ** & 10.00 \\
Soybean oil & 0.60 \\
Vit. and min. mix* & 0.30 \\
Di-calcium phosphat & 0.10 \\
Dl-methionine & 0.05 \\
Total & 100.00 \\
Calculated analysis ${ }^{1}$ : & \\
Crude protein, \% & 24.01 \\
Ether extract, \% & 2.83 \\
Crude fiber, \% & 3.71 \\
Calcium , \% & 0.87 \\
Available phosphorus, \% & 0.45 \\
Methionine, \% & 0.55 \\
Lysine , \% & 1.29 \\
Metabolizable energy (Kcal/Kg diet) & 2874.79 \\
\hline *Each Kg of vitamin and minerals mixture contained: Vit. A, 4,000,000IU; Vit.D3, 500,000 IU; Vit.E, 16.7 g.; Vit. K, 0.67 \\
g.; Vit. B1, 0.67 g.; Vit.B2, 2g.; Vit. B6, 0.67g.; Vit. B12, 0.004g.; Nicotinic acid, 16.7 g.; Pantothenic acid, 6.67 g.; Biotin, \\
0.07 g.; Folic acid, 1.67 g.; Choline chloride, 400g.; Zn, 23.3g.; Mn, 10g.; Fe, 25g.; Cu, 1.67g.; I, 0.25g.; Se, 0.033g.; Mg, \\
133.4g. \\
**Broiler concentrate: ME (Kcal/Kg) 2500, Crude protein 52\%, Methionine 1.5 \%, Methionine \& cystine 2.0\%, Lysine 2.9 \\
\%, Calcium 7.4 \%, Phosphorus 3\%, NaCl 2 \%, Crude fiber 2.3\%, Crude fat 4 \%. ${ }^{1}$ According to NRC(1994).
\end{tabular}

Live body weight and feed consumed were recorded at 6 week of age for each replicate. Body weight gain and feed conversion ratio (gm feed: gm gain) were calculated for each replicate throughout experimental period. Mortality rate was monitored daily. Six birds representing the average live weight in each treatment were selected and sacrificed to determine blood parameters, carcass traits, immunological parameters and the relative weight of lymphoid organs (spleen, bursa and thymus).

Blood samples were divided into two equal parts. The first was collected on heparin as anticoagulant ( $0.1 \mathrm{ml}$ of heparin to $1 \mathrm{ml}$ of blood) according to Hawk et al. (1965) to determine the blood hematological parameters. The second part was kept to clot and then centrifuged at $4000 \mathrm{rpm}$ for 15 minutes to separate blood serum. The obtained serum was kept frozen at $-18{ }^{\circ} \mathrm{C}$ then analyzed.

All biochemical analyses (total protein, albumin, alkaline phosphatase alanine aminotransferase, aspartete aminotransferese, total lipids, total cholesterol, height density lipoproteins (HDL), low density Lipoproteins (LDL), triglyceride, uric acid , creatinine, total antioxidant capacity, glutathione peroxidase and lipid peroxide were done by using commercial kits produced by bio - diagnostic - Egypt (www.bio-diagnostic.com). Serum globulin was estimated by subtracting albumin values from the corresponding values of total protein. Phagocytic activity was determined according to Kawahara et al. (1991). Fifty $\mu \mathrm{g}$ Candida albicans culture (previously adjusted to $1 \mathrm{gm}$ Candida albicans/ $100 \mathrm{ml}$ saline) was added to $1 \mathrm{ml}$ of citrated blood collected from infected and control quail and shaken in water bath at $23-25{ }^{\circ} \mathrm{C}$ for 3-5 hours. Smears of the blood were stained with Giemsa solution. Phagocytosis was estimated by determining the proportion of macrophages which contained intracellular yeast cells in a random count of 300 phagocytes and expressed as percentage of phagocytic activity (PA). The number of phagocytized organisms was counted in the phagocytic cells and called phagocytic index (PI). Results were expressed as means \pm S.E. and differences were evaluated by Student's t-test (Snedicor and Cochran, 1980).

Phagocytic activity (PA) = Percentage of phagocytic cells containing yeast cells.

Phagocytic index $=\frac{\text { Number of yeast cells phagocytized }}{\text { Number of phagocytic cells }}$

At 3 weeks of age for all birds were vaccinated against NDV vaccine using HBI strain. Blood samples (4 samples from each treatment) were collected at 14 and 21 days after vaccination and immediately centrifuged at $4000 \mathrm{rpm}$ for $15 \mathrm{~min}$., to separate serum. The Haemagglutination -Inhibition test (HI) was used to determine humoral -antibody titter against Newcastle disease virus (NDV).

For the histological studies, tissue specimens of liver, spleen, bursa of fabricius and thymus were rapidly fixed in $10 \%$ neutral buffered formalin solution. The fixed specimens were processed through the conventional paraffin embedding technique. Paraffin blocks were prepared from which 5 microns thick sections were obtained. These sections were stained by Hematoxyline and Eosin (H\&E) according to the method described by Culling (1983).

Histometrical studies were done thymus and bursa of fabricius using micro image analysis software (PHMIAS 2006 Ver 2.1) to measure total number of follicles, number of large and small follicles in bursa of fabricius and percentage of follicular cortex in thymus. 
The data obtained were analyzed statistically using the one way ANOVA procedure of SPSS ${ }^{\circledR}$ (Windows Version of SPSS, release 16) with Duncan's Multiple Range Test (Duncan, 1955) to identify the significant differences between the means.

\section{RESULTS AND DISCUSSIONS}

The effects of propolis supplementation on productive performance at six weeks of age are presented in Table (2). Groups that fed diets containing different levels of propolis had significantly heavier body weights than control group. The highest $(\mathrm{P} \leq 0.01)$ value was observed in quail fed $300 \mathrm{mg} / \mathrm{kg}$ as compared to the other experimental groups. This group surpassed the control one by $7.7 \%$.

Table 2. Effect of propolis supplementation on productive performance of growing Japanese quail from throughout experimental period

\begin{tabular}{lccccc}
\hline Treatments & $\begin{array}{c}\text { Initial body } \\
\text { weight }(\mathrm{g})\end{array}$ & $\begin{array}{c}\text { Final body } \\
\text { weight }(\mathrm{g})\end{array}$ & $\begin{array}{c}\text { body weight } \\
\text { gain }(\mathrm{g})\end{array}$ & $\begin{array}{c}\text { Feed } \\
\text { consumption } \\
(\mathrm{g} / \mathrm{bird})\end{array}$ & $\begin{array}{c}\text { Feed conversion ratio } \\
\text { (g feed/g gain) }\end{array}$ \\
\hline $\mathrm{T}_{1}($ Control $)$ & $18.26 \pm 0.40$ & $183.30 \pm 0.35^{\mathrm{d}}$ & $165.04 \pm 0.37^{\mathrm{d}}$ & $603.33 \pm 0.34^{\mathrm{d}}$ & $3.66 \pm 0.34^{\mathrm{a}}$ \\
$\mathrm{T}_{2}(75 \mathrm{mg} / \mathrm{kg})$ & $18.25 \pm 0.35$ & $187.46 \pm 0.24^{\mathrm{c}}$ & $169.21 \pm 0.33^{\mathrm{c}}$ & $609.05 \pm 0.70^{\mathrm{c}^{\prime}}$ & $3.60 \pm 0.50^{\mathrm{a}}$ \\
$\mathrm{T}_{3}(150 \mathrm{mg} / \mathrm{kg})$ & $18.24 \pm 0.25$ & $189.27 \pm 0.36^{\mathrm{b}}$ & $171.03 \pm 0.40^{\mathrm{b}}$ & $616.81 \pm 0.22^{\mathrm{b}}$ & $3.61 \pm 0.50^{\mathrm{a}}$ \\
$\mathrm{T}_{4}(225 \mathrm{mg} / \mathrm{kg})$ & $18.25 \pm 0.32$ & $190.02 \pm 0.35^{\mathrm{b}}$ & $171.77 \pm 0.39^{\mathrm{b}}$ & $618.52 \pm 0.34^{\mathrm{b}}$ & $3.60 \pm 0.24^{\mathrm{a}}$ \\
$\mathrm{T}_{5}(300 \mathrm{mg} / \mathrm{kg})$ & $18.26 \pm 0.63$ & $197.50 \pm 0.72^{\mathrm{a}}$ & $179.24 \pm 0.51^{\mathrm{a}}$ & $629.97 \pm 0.45^{\mathrm{a}}$ & $3.51 \pm 0.42^{\mathrm{b}}$ \\
$\mathrm{P}$ value & 0.621 & 0.012 & 0.018 & 0.012 & 0.053 \\
\hline
\end{tabular}

${ }^{\mathrm{a}-\mathrm{d}}$ Means in the same row having different letters are significantly different.

The effect of propolis supplementations on live body weight gain of growing Japanese quail had the same trend that observed on body weight.

This observation is in harmony with the results of Tekli et al. (2011) who approved that propolis significantly improved weight gain of broilers. Also, Haro et al. (2000) mentioned that, propolis increased the weight gain of rat. They demonstrated that these benefits could be attributed to the fact that digestive functions are favored by this dietary supplement.

In contrast Silici et al. (2007) reported that, propolis had no determintal effect on the health but did not improve the performance parameters of quail in the first 35 days of age. Also, Mahmoud et al. (2013) observed that addition of $100,250,500$ and $750 \mathrm{mg} / \mathrm{kg}$ propolis not improved broiler performance.

Recently, Kleczek et al. (2014) mentioned that, the final body weights of broiler chickens during the rearing period did not differ significantly between groups given propolis or control diets.

The current results also showed that feed intake increased with the increasing propolis levels. This results are in agreement with those reported by Denli et al. (2004), on fattening quail and by Daneshmand et al. (2012) on broilers. Controversially, Sahin et al. (2003), Acikgoz et al. (2005) and Canogullari et al. (2009) indicated that the dietary supplementation of birds with propolis had no significant effect on average daily feed consumption when compared with control group.

The best $(P \leq 0.05)$ value of feed conversion ratio was noticed in group fed $300 \mathrm{mg}$ propolis $/ \mathrm{kg}$ as compared with other experimental groups. This improvement in feed conversion ratio could be attributed to their antimicrobial, antioxidant activity and improving nutrient utilization due to the presence of phenolic and flavonoids compounds (Tatli seven $e t$ al., 2009 and Haro et al. 2000).

Mortality rate of birds fed diets containing different levels of propolis were significantly $(\mathrm{P} \leq 0.01)$ decreased as compared with the control group (Fig. 1). These results confirmed the findings of Hegazi et al. (1995) who found that mortality rate was reduced in groups infected with virulent NDV and treated with propolis. Also, Shalmany and Shivazad (2006) reported that chicks fed propolis decreased mortality rate as compared to those fed control diet.

The relative weights of carcass, liver, gizzard, spleen, bursa and thymus were significantly $(\mathrm{P} \leq 0.05$ or 0.01 ) affected by propolis supplementation, except relative weight of heart (Table 3 ). Hegazi et al. (1996) recorded an increase in thymus weight after 14 days post injection with propolis up to the end of the experiment. Meanwhile, spleen weight slightly affected, but bursa weight was increased at the last two weeks of the experiment. On the other hand, Denli et al. (2005) found that quail fed with flavomycin at $10 \mathrm{mg} / \mathrm{kg}$ diet and propolis at $0.5,1$ and $1.5 \mathrm{~g} / \mathrm{kg}$ diet had no significant differences in carcass yield, liver and gizzard. Also, Kleczek et al. (2014) found that the carcass weight during the rearing period did not differ significantly between broilers groups fed diets containing antibiotic, propolis or control group. 


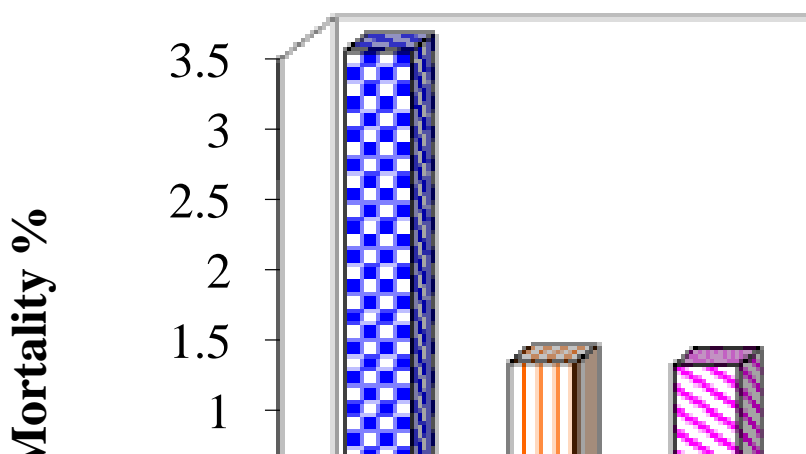

Fig. 1. Effect of propolis supplementation on mortality rate of growing Japanese quail.

Table 3. Effect of propolis supplementation on relative weight of carcass and lymphoid organs of growing Japanese quail at 6 weeks of age

\begin{tabular}{cccccccc}
\hline Treatments & Carcass & Liver & Gizzard & Heart & Spleen & Bursa & Thymus \\
\hline $\mathrm{T}_{1}($ Control $)$ & $68.57 \pm 0.23^{\mathrm{b}}$ & $2.44 \pm 0.13^{\mathrm{b}}$ & $3.36 \pm 0.22^{\mathrm{b}}$ & $1.33 \pm 0.05$ & $0.06 \pm 0.02^{\mathrm{c}}$ & $0.12 \pm 0.02^{\mathrm{c}}$ & $0.32 \pm 0.11^{\mathrm{b}}$ \\
$\mathrm{T}_{2}(75 \mathrm{mg} / \mathrm{kg})$ & $68.73 \pm 0.33^{\mathrm{b}}$ & $3.40 \pm 0.06^{\mathrm{a}}$ & $3.44 \pm 0.23^{\mathrm{b}}$ & $1.35 \pm 0.20$ & $0.13 \pm 0.01^{\mathrm{b}}$ & $0.15 \pm 0.04^{\mathrm{c}}$ & $0.36 \pm 0.11^{\mathrm{b}}$ \\
$\mathrm{T}_{3}(150 \mathrm{mg} / \mathrm{kg})$ & $69.47 \pm 0.60^{\mathrm{b}}$ & $3.48 \pm 0.46^{\mathrm{a}}$ & $3.66 \pm 0.42^{\mathrm{ab}}$ & $1.35 \pm 0.30$ & $0.15 \pm 0.02^{\mathrm{b}}$ & $0.15 \pm 0.02^{\mathrm{c}}$ & $0.36 \pm 0.03^{\mathrm{b}}$ \\
$\mathrm{T}_{4}(225 \mathrm{mg} / \mathrm{kg})$ & $69.98 \pm 0.54^{\mathrm{a}}$ & $3.50 \pm 0.21^{\mathrm{a}}$ & $3.69 \pm .31^{\mathrm{ab}}$ & $1.47 \pm 0.21$ & $0.16 \pm 0.03^{\mathrm{b}}$ & $0.23 \pm 0.01^{\mathrm{b}}$ & $0.36 \pm 0.12^{\mathrm{b}}$ \\
$\mathrm{T}_{5}(300 \mathrm{mg} / \mathrm{kg})$ & $70.05 \pm 0.04^{\mathrm{a}}$ & $3.54 \pm 0.35^{\mathrm{a}}$ & $4.33 \pm 0.25^{\mathrm{a}}$ & $1.45 \pm 0.08$ & $0.22 \pm 0.01^{\mathrm{a}}$ & $0.32 \pm 0.03^{\mathrm{a}}$ & $0.44 \pm 0.13^{\mathrm{a}}$ \\
P value & 0.050 & 0.012 & 0.053 & 0.420 & 0.010 & 0.014 & 0.052 \\
\hline${ }_{\mathrm{a}-\mathrm{c}}$ & & &
\end{tabular}

${ }^{\mathrm{a}-\mathrm{c}}$ Means in the same row having different letters are significantly different.

The results revealed that at 14 days post vaccination, white blood cells counts, packed cell volume, lymphocytes $(\mathrm{L})$, heterophils $(\mathrm{H}), \mathrm{H} / \mathrm{L}$ ratio, monocytes, basophils, eosinophils, hemoglobin concentration, phagocytic activity and phagocytic index were not significantly affected by different treatments. However, red blood cells counts were significantly $(\mathrm{P} \leq 0.05)$ affected by propolis treatments (Table 4). It was observed that group received $300 \mathrm{mg}$ propolis had the significantly highest red blood cells counts as compared to other groups. At 21days post-vaccination, the results indicated that, red blood cells and white blood cells counts, packed cell volume, heterophils, H/L ratio, monocytes, basophils, eosinophils, phagocytic activity, and phagocytic index were not significantly affected by propolis treatments, while hemoglobin concentration and lymphocytes transformation test were significantly $(\mathrm{P} \leq 0.05)$ increased by propolis treatments (Table 5$)$.

Antibody titers against Newcastle disease virus of propolis groups were significantly $(\mathrm{P} \leq 0.001)$ superior over that in control group at 14 and 21days postvaccination. In this respect, Jasprica et al. (2007) found that administration of propolis did not cause any significant change in blood cells, $\mathrm{Hb}$ concentration and hematocrit of human. In addition, Çetin et al. (2010b) reported that propolis at 100 ppm did not cause any significant alteration on PCV, total leukocyte counts, neutrophil, lymphocytes, monocytes, eosinophil and basophil indices in rats. On the other hand, the effect of propolis supplementation on hematological criteria was shown by El-Hanoun et al. (2007b) and Kamel et al. (2007) demonstrated that propolis (100, 200 and $300 \mathrm{ppm})$ increased leukocyte counts especially lymphocytes.
Also, Çetin et al. (2010a) showed that treatment of rats with proptamphos plus propolis increased total leukocyte count and neutrophil percentage but lymphocyte percentage decreased.

Propolis increased in vivo cellular immunity (Galal et al., 2008) and increased antibody titers in virulent NDV infected chicks and phagocytic percentage (Hegazi et al., 1995; 1996 and 2012). The present results may indicate an immunestimulatory effect of propolis. It has been reported that propolis has a direct regulatory effect on the basic functional properties of immune cells (Ansorge et al., 2003). Artepillin C which is one of propolis components has been described to activate the immune system by increasing phagocytic activity as well as number of lymphocytes (Kimoto et al., 1998). Propolis extract may increase production of the lymphocyte activating factor IL-1 which enhances Band T-cell proliferation (Orsolic and Basic, 2003; Chu, 2006)

The positive effect of propolis observed herein could be attributed to its anti-bacterial action (Orsi et al., 2006 and Scazzochio et al., 2006), antiviral (Gekker et al., 2005), antifungal (Sforcin et al., 2001), antiparasite (Freitas et al., 2006), antiinflammatory (Dobrowolski et al., 1991), immunomodulatory (Dimov et al., 1992), antioxidant (Krol et al., 1990), essential and aromatic oils, protein, amino acid, vitamins and flavonoids, microelements like aluminium and calcium (Marcucci, 1995; Burdock, 1998 and Lee et al., 2001), increasing the numbers of beneficial bacteria (Lactobacillus spp) in jejunum (Tekeli et al., 2011) and this accompanied with decreasing numbers of harmful bacteria (Coliform and E. coli). 
The data obtained on serum biochemical estimates in quails as affected by propolis are presented in Table (6). The results showed that a little difference in serum total protein and globulin level of propolis groups as compared with control group, the results also showed that albumen was not significantly differing in all groups. Abdel-Rahman and Mosaad, (2013) reported that adding $2 \mathrm{~g}$ propolis $/ \mathrm{kg}$ diet of Muscovy ducks maintained at $33^{\circ} \mathrm{C}$ was reflected with significant higher contents of its serum total protein, albumin and total globulin. Mahmoud et. al. (2013) found that the addition of $250 \mathrm{mg} / \mathrm{kg}$ propolis, insignificantly increased the serum total protein and total globulin concentrations and decreased the albumin / globulin ratio. But, the highest doses $(750 \mathrm{mg} / \mathrm{kg})$ had the conversely affect.

Table 4. Effect of propolis supplementation on some hematological and immunological parameters of growing Japanese quail at 14 days post vaccination

\begin{tabular}{|c|c|c|c|c|c|c|}
\hline \multirow[b]{2}{*}{ Items } & \multicolumn{6}{|c|}{ Dietary treatments* } \\
\hline & $\mathrm{T} 1$ & $\mathrm{~T} 2$ & $\mathrm{~T} 3$ & $\mathrm{~T} 4$ & $\mathrm{~T} 5$ & $\begin{array}{c}\mathrm{P} \\
\text { value }\end{array}$ \\
\hline Red blood cells (RBCs $10^{6} / \mathrm{mm}^{3}$ ) & $1.83 \pm 0.07^{\mathrm{bc}}$ & $1.97 \pm 0.07^{\mathrm{b}}$ & $1.67 \pm 0.03^{\mathrm{c}}$ & $1.97 \pm 0.07^{\mathrm{b}}$ & $2.27 \pm 0.09^{\mathrm{a}}$ & 0.001 \\
\hline $\begin{array}{l}\text { White blood cells (WBCs } \\
10^{3} / \mathrm{mm}^{3} \text { ) }\end{array}$ & $21.00 \pm 1.00$ & $21.33 \pm 1.45$ & $21.67 \pm 0.33$ & $21.33 \pm 0.88$ & $22.33 \pm 0.67$ & 0.880 \\
\hline Hemoglobin (Hb g/dl) & $10.33 \pm 0.67$ & $10.33 \pm 0.33$ & $10.00 \pm 0.58$ & $9.67 \pm 0.33$ & $11.00 \pm 0.00$ & 0.361 \\
\hline Packed cell volume (PCV \%) & $30.33 \pm 1.20$ & $31.00 \pm 0.00$ & $29.00 \pm 1.15$ & $29.67 \pm 0.88$ & $32.00 \pm 1.00$ & 0.277 \\
\hline Lymphocytes & $51.33 \pm 1.76$ & $52.33 \pm 1.45$ & $50.67 \pm 2.33$ & $52.00 \pm 0.58$ & $49.00 \pm 1.73$ & 0.657 \\
\hline Heterophils & $39.67 \pm 1.20$ & $37.33 \pm 1.76$ & $39.33 \pm 2.33$ & $38.33 \pm 0.33$ & $41.00 \pm 1.15$ & 0.530 \\
\hline $\mathrm{H} / \mathrm{L}$ ratio & $0.78 \pm 0.05$ & $0.72 \pm 0.05$ & $0.78 \pm 0.08$ & $0.74 \pm 0.01$ & $0.84 \pm 0.05$ & 0.572 \\
\hline Monocytes & $8.33 \pm 0.33$ & $9.00 \pm 0.58$ & $8.33 \pm 0.33$ & $8.00 \pm 0.58$ & $9.00 \pm 0.00$ & 0.398 \\
\hline Basophils & $0.33 \pm 0.33$ & $0.67 \pm 0.33$ & $0.67 \pm 0.33$ & $0.67 \pm 0.33$ & $0.67 \pm 0.33$ & 0.933 \\
\hline Eosinophils & $0.33 \pm 0.33$ & $0.67 \pm 0.33$ & $1.00 \pm 0.00$ & $1.00 \pm 0.00$ & $0.33 \pm 0.33$ & 0.233 \\
\hline \multicolumn{7}{|l|}{ Immunity parameters } \\
\hline$\overline{\text { Phagocytic activity (PA) }}$ & $20.67 \pm 0.33$ & $22.33 \pm 1.45$ & $23.00 \pm 1.53$ & $21.33 \pm 0.88$ & $22.00 \pm 1.15$ & 0.666 \\
\hline Phagocytic index (PI \%) & $2.03 \pm 0.18$ & $1.90 \pm 0.15$ & $1.90 \pm 0.06$ & $1.90 \pm 0.10$ & $1.93 \pm 0.15$ & 0.940 \\
\hline Antibody titer against NDV & $1.33 \pm 0.33^{\mathrm{c}}$ & $3.33 \pm 0.33^{\mathrm{b}}$ & $3.00 \pm 0.00^{\mathrm{b}}$ & $3.00 \pm 0.00^{\mathrm{b}}$ & $4.00 \pm 0.00^{\mathrm{a}}$ & 0.001 \\
\hline
\end{tabular}

Table 5. Effect of propolis supplementation on some hematological and immunological parameters of growing Japanese quail at 21 days post vaccination

\begin{tabular}{|c|c|c|c|c|c|c|}
\hline \multirow[b]{2}{*}{ Items } & \multicolumn{6}{|c|}{ Dietary treatments* } \\
\hline & $\mathrm{T} 1$ & $\mathrm{~T} 2$ & T3 & $\mathrm{T} 4$ & T5 & $\begin{array}{c}\mathrm{P} \\
\text { value }\end{array}$ \\
\hline $\begin{array}{l}\text { Red blood cells (RBCs } \\
\left.10^{6} / \mathrm{mm}^{3}\right)\end{array}$ & $1.87 \pm 0.15$ & $1.87 \pm 0.22$ & $1.83 \pm 0.13$ & $1.83 \pm 0.15$ & $1.93 \pm 0.09$ & 0.989 \\
\hline $\begin{array}{l}\text { White blood cells (WBCs } \\
10^{3} / \mathrm{mm}^{3} \text { ) }\end{array}$ & $20.67 \pm 0.88$ & $21.33 \pm 1.20$ & $22.00 \pm 0.58$ & $20.67 \pm 0.33$ & $21.67 \pm 0.67$ & 0.690 \\
\hline Hemoglobin (Hb g/dl) & $7.67 \pm 0.33^{\mathrm{b}}$ & $10.00 \pm 0.58^{\mathrm{a}}$ & $8.33 \pm 0.33^{\mathrm{ab}}$ & $9.00 \pm 1.00^{\mathrm{ab}}$ & $9.00 \pm 0.58^{\mathrm{ab}}$ & 0.041 \\
\hline Packed cell volume (PCV \%) & $24.67 \pm 0.88$ & $29.33 \pm 1.67$ & $25.67 \pm 0.88$ & $28.33 \pm 3.18$ & $28.67 \pm 1.45$ & 0.348 \\
\hline Lymphocytes & $51.67 \pm 0.33$ & $48.00 \pm 1.00$ & $47.33 \pm 3.18$ & $47.67 \pm 2.33$ & $48.00 \pm 0.58$ & 0.487 \\
\hline Heterophils & $38.33 \pm 0.33$ & $42.00 \pm 0.58$ & $43.00 \pm 2.52$ & $42.33 \pm 2.19$ & $42.67 \pm 0.67$ & 0.273 \\
\hline $\mathrm{H} / \mathrm{L}$ ratio & $0.74 \pm 0.01$ & $0.88 \pm 0.03$ & $0.92 \pm 0.12$ & $0.90 \pm 0.09$ & $0.89 \pm 0.02$ & 0.432 \\
\hline Monocytes & $8.67 \pm 0.33$ & $8.67 \pm 0.33$ & $8.67 \pm 0.33$ & $9.00 \pm 0.00$ & $8.67 \pm 0.67$ & 0.962 \\
\hline Basophils & $0.67 \pm 0.33$ & $1.00 \pm 0.00$ & $0.33 \pm 0.33$ & $0.67 \pm 0.33$ & $0.33 \pm 0.33$ & 0.512 \\
\hline Eosinophils & $0.67 \pm 0.33$ & $0.33 \pm 0.33$ & $0.67 \pm 0.33$ & $0.33 \pm 0.33$ & $0.33 \pm 0.33$ & 0.871 \\
\hline \multicolumn{7}{|l|}{ Immunity parameters } \\
\hline$\overline{\text { Phagocytic activity (PA) }}$ & $22.33 \pm 0.88$ & $22.00 \pm 0.58$ & $21.33 \pm 1.20$ & $21.67 \pm 1.20$ & $22.33 \pm 0.33$ & 0.348 \\
\hline Phagocytic index (PI \%) & $2.00 \pm 0.15$ & $2.00 \pm 0.12$ & $2.13 \pm 0.09$ & $2.10 \pm 0.12$ & $1.90 \pm 0.12$ & 0.670 \\
\hline Antibody titer against NDV & $2.33 \pm 0.33^{\mathrm{c}}$ & $4.67 \pm 0.33^{\mathrm{b}}$ & $4.00 \pm 0.00^{\mathrm{b}}$ & $4.67 \pm 0.33^{\mathrm{b}}$ & $5.67 \pm 0.33^{\mathrm{a}}$ & 0.001 \\
\hline
\end{tabular}


Table 6. Effect of propolis supplementation on some blood serum constituents of growing Japanese quail at 6 weeks of age

\begin{tabular}{|c|c|c|c|c|c|c|}
\hline \multirow[b]{2}{*}{ Items } & \multicolumn{6}{|c|}{ Dietary treatments* } \\
\hline & $\mathrm{T} 1$ & $\mathrm{~T} 2$ & $\mathrm{~T} 3$ & $\mathrm{~T} 4$ & T5 & $\begin{array}{c}\mathrm{P} \\
\text { value }\end{array}$ \\
\hline Total Protein $(\mathrm{g} / \mathrm{dl})$ & $3.72 \pm 0.10^{\mathrm{b}}$ & $4.07 \pm 0.26^{\mathrm{ab}}$ & $4.34 \pm 0.05^{\mathrm{a}}$ & $4.06 \pm 0.12^{\mathrm{ab}}$ & $4.08 \pm 0.10^{\mathrm{ab}}$ & 0.010 \\
\hline Albumin (g/dl) & $2.48 \pm 0.12$ & $2.67 \pm 0.23$ & $2.40 \pm 0.25$ & $2.67 \pm 0.14$ & $2.70 \pm 0.14$ & 0.711 \\
\hline Globulin (g/dl) & $1.24 \pm 0.09^{\mathrm{b}}$ & $1.40 \pm 0.14^{\mathrm{b}}$ & $1.94 \pm 0.26^{\mathrm{a}}$ & $1.39 \pm 0.14^{\mathrm{b}}$ & $1.38 \pm 0.13^{b}$ & 0.005 \\
\hline Alkaline phosphatase (IU/L) & $91.40 \pm 8.76$ & $104.40 \pm 10.40$ & $96.60 \pm 10.63$ & $91.40 \pm 5.49$ & $97.20 \pm 6.22$ & 0.813 \\
\hline Alanine aminotransferase (U/L) & $11.90 \pm 0.24$ & $12.20 \pm 0.37$ & $11.20 \pm 0.37$ & $12.40 \pm 0.68$ & $11.20 \pm 0.37$ & 0.199 \\
\hline $\begin{array}{l}\text { Aspartete aminotransferese } \\
\text { (U/L) }\end{array}$ & $9.20 \pm 0.58^{b}$ & $11.20 \pm 0.73^{\mathrm{ab}}$ & $11.20 \pm 0.80^{\mathrm{ab}}$ & $11.40 \pm 0.51^{\mathrm{a}}$ & $11.20 \pm 0.58^{\mathrm{ab}}$ & 0.033 \\
\hline Total lipids (mg/dl) & $457.20 \pm 18.9^{\mathrm{a}}$ & $302.20 \pm 13.7^{\mathrm{c}}$ & $309.14 \pm 18.3^{\mathrm{c}}$ & $399.40 \pm 28.05^{\mathrm{ab}}$ & $380.20 \pm 27.7^{b}$ & 0.001 \\
\hline Total Cholesterol (mg/l) & $146.20 \pm 6.87^{\mathrm{a}}$ & $106.00 \pm 4.42^{\mathrm{b}}$ & $115.60 \pm 4.72^{\mathrm{b}}$ & $115.80 \pm 6.30^{\mathrm{b}}$ & $104.00 \pm 2.26^{\mathrm{b}}$ & 0.018 \\
\hline Low density lipoprotein (mg/l) & $32.20 \pm 2.58$ & $33.20 \pm 1.32$ & $28.40 \pm 0.93$ & $33.80 \pm 1.20$ & $34.60 \pm 3.41$ & 0.299 \\
\hline High density lipoprotein (mg/l) & $94.45 \pm 1.51^{\mathrm{a}}$ & $55.08 \pm 3.63^{\mathrm{b}}$ & $55.00 \pm 0.77^{\mathrm{b}}$ & $81.92 \pm 10.42^{\mathrm{a}}$ & $63.12 \pm 3.79^{b}$ & 0.001 \\
\hline Triglycerides (mg/dl) & $110.14 \pm 4.87^{\mathrm{a}}$ & $98.22 \pm 1.63^{b}$ & $91.20 \pm 1.02^{b}$ & $92.40 \pm 3.04^{\mathrm{b}}$ & $90.80 \pm 2.75^{b}$ & 0.001 \\
\hline Uric acid (mg/dl) & $5.64 \pm 0.35^{\mathrm{a}}$ & $5.78 \pm 0.61^{\mathrm{a}}$ & $4.02 \pm 0.53^{\mathrm{b}}$ & $4.54 \pm 0.38^{\mathrm{ab}}$ & $3.98 \pm 0.63^{\mathrm{b}}$ & 0.049 \\
\hline Creatinine (mg/dl) & $0.68 \pm 0.14^{\mathrm{ab}}$ & $0.66 \pm 0.07^{\mathrm{ab}}$ & $0.76 \pm 0.13^{\mathrm{a}}$ & $0.36 \pm 0.04^{\mathrm{c}}$ & $0.40 \pm 0.06^{\mathrm{bc}}$ & 0.025 \\
\hline Glutathione peroxidase $(\mathrm{mu} / \mathrm{ml})$ & $31.42 \pm 1.80^{\mathrm{b}}$ & $30.30 \pm 2.10^{\mathrm{b}}$ & $30.64 \pm 0.83^{b}$ & $33.89 \pm 0.51^{\mathrm{ab}}$ & $36.50 \pm 0.64^{\mathrm{a}}$ & 0.019 \\
\hline Lipid peroxide (nmol/ ml) & $11.21 \pm 0.27^{\mathrm{a}}$ & $10.57 \pm 0.28^{\mathrm{ab}}$ & $10.04 \pm 0.28^{b c}$ & $9.85 \pm 0.23^{b c}$ & $9.36 \pm 0.16^{\mathrm{c}}$ & 0.001 \\
\hline $\begin{array}{l}\text { total antioxidant capacity } \\
(\mathrm{mg} / \mathrm{dl})\end{array}$ & $0.545 \pm 0.09^{c}$ & $0.607 \pm 0.08^{\mathrm{bc}}$ & $0.670 \pm 0.05^{\mathrm{bc}}$ & $0.898 \pm 0.02^{\mathrm{a}}$ & $0.781 \pm 0.04^{\mathrm{ab}}$ & 0.008 \\
\hline
\end{tabular}

$* \mathrm{~T}_{1}$ (Control) ${ }^{-} \mathrm{T}_{2}$ (Control $+75 \mathrm{mg}$ propolis/kg diet) - $\mathrm{T} 3$ (Control +150 mg propolis/kg diet) - $\mathrm{T}_{4}(\mathrm{Control}+225 \mathrm{mg}$ propolis/kg diet) -T5 (Control $+300 \mathrm{mg}$ propolis/kg diet).

a - c Means in the same row having different letters are significantly different.

The different levels of propolis did not significantly $(\mathrm{P} \leq 0.05)$ influence the serum alkaline phosphatase and alanine aminotransferase of growing quail, while serum aspartete aminotransferese significantly $(\mathrm{P} \leq 0.05)$ increased in the group given $225 \mathrm{mg}$ propolis diet in comparison with control. Serum uric acid significantly $(\mathrm{P} \leq 0.05)$ affected by different treatments. It was observed that uric acid concentration decreased in the groups fed 150, 225 and $300 \mathrm{mg}$ propolis than other groups. Serum creatinine concentration was significantly $(\mathrm{P} \leq 0.05)$ decreased due to addition of $225 \mathrm{mg}$ propolis as compared with control group; However, the other experimental treatments were significantly equal to the control group.

The obtained results were in agreement with those reported by Khalil and El-Sheikh (2010) who reported that propolis 1000 and 2000 ppm in rat diets decreased the toxic effect of fluoride by a significant decrease in ALP activity, urea and creatinine. In the study of Abbas (2012) propolis tended to have an increase in the serum creatinine level and did not provoke changes in the serum urea level when compared to control; a finding which might suggest that bee propolis provides an additional protective effect against kidney injury (Nagyova et al., 1994). Findings on ALT and AST concentration in serum suggested the presence of a hepato-protective activity for propolis as indicated by maintaining AST, ALT and alkaline phosphatase activities in liver. Previous studies demonstrated that quinic acid derivatives naturally present in propolis have strong liverprotective effects and promote healing of toxic liver cells (Seo et al., 2003).

As shown in Table (6), serum total lipids, cholesterol, high density lipoprotein and triglycerides significantly $(\mathrm{P} \leq 0.01)$ decreased with inclusion of different levels of propolis as compared to the control group. The lowest values were recorded in the group fed 75, 150, 225 and $300 \mathrm{mg}$ propolis, respectively. These groups had the lowest in total lipids, cholesterol, high density lipoprotein and triglycerides than control group by $33.90,28.86,41.77$ and $17.56 \%$, respectively.

These results are in agreement (less or more) with those obtained by Babaei et al. (2004) who reported that Japanese quail fed diet containing $1000 \mathrm{ppm}$ alcoholic extract of propolis significantly $(\mathrm{P} \leq 0.01)$ lowered total cholesterol, triglycerides and low density lipoprotein and increased level of high density lipoprotein in the blood as compared with quail fed control diet. Similarly, Kolankaya et al. (2002) found that HDL level increased and LDL cholesterol and triglyceride levels were decreased by giving propolis with $200 \mathrm{mg} / \mathrm{kg}$ body weight/day in rats. It was expressed in the findings of diverse studies that propolis intake lead to a decrease in the level of plasma triglycerids concentrations (Fuliang et al., 2005). This lowering effect can be attributed to the regulatory mechanism of the flavanoids as one of the ingredients in these natural products for blood circulation and stimulation of triglycerids use for energy generation. (Tekeli et al, 2011). On the other hand, Daneshmand et al. (2015) reported that propolis supplementation in broiler chicken diet resulted in non-significant difference was detected with regard to serum lipid profile as compared with control. Also, Denli et al. (2005) demonstrated that propolis had no significant effect on triglycerides, total cholesterol, high density lipoprotein and low density lipoprotein in quail compared to the control.

Serum glutathione peroxidase activity was significantly $(\mathrm{P} \leq 0.01)$ increased in the groups had 
$300 \mathrm{mg}$ propolis in their diet as compared to the control group (Table 6). Serum total antioxidant capacity was significantly $(\mathrm{P} \leq 0.01)$ increased in the groups had 225 and $300 \mathrm{mg}$ propolis in their diet as compared to groups had 75 and $150 \mathrm{mg}$ propolis and the control group, while serum lipid peroxide concentration was significantly $(\mathrm{P} \leq 0.001)$ decreased by increasing propolis levels in the diets (except the group had $75 \mathrm{mg}$ propolis was significantly equal to the control group). It was recorded by Jeon et al. (2002) that flavonoids from propolis have been reported to elevate catalase, superoxide dismutase and glutathione peroxidase mRNA synthesis. By increasing the activities of antioxidant enzymes, flavonoids from propolis reduce the number of free radicals or ROS generated and increase the production of molecules protecting against oxidative stress. Experimental evidence has demonstrated that propolis and its polyphenolic/flavonoid components increased the activities of superoxide dismutase (SOD), catalase (CAT), glutathione peroxidase (GPx), glutathione reductase (GR), and glutathione (GSH) (Molina et al., 2003 and Orsolic and Basic., 2005). Several flavonoids have been reported to protect against DNA damage (Russo et al., 2000). The radical scavening abilities and effects of flavonoids from propolis on the activities of enzymes involved in antioxidative defense provide a reasonable explanation for the decreased of DNA damage in leukocytes of mice treated before or after irradiation with propolis and its flavonoids in this investigation. It is likely that more different cooperative and synergistic mechanisms of propolis and its polyphenlic compounds are included in protection of organism against radiation. The increase of antioxidant enzyme activities such as SOD, CAT and GSH may be considered as a protective mechanism against heat-induced free radical production and lipid peroxidation (Tatli Seven et al., 2009).

Histological analyses in the bursa of fabricius and thymus are presented in (Table 7). Microscopically investigations in bursa of babricius indicate that, the total number of follicles and the small follicles in Japanese quail supplemented with 225 and $300 \mathrm{mg}$ propolis $/ \mathrm{kg}$ were significantly $(\mathrm{P} \leq 0.01)$ lower than control treatment $(\mathrm{P} \geq 0.05)$. As shown in Table (7), supplementation of 225 and $300 \mathrm{mg}$ propolis $/ \mathrm{kg}$ increased the diameter of large follicles and the diameter of small follicles compared with other treatments, meanwhile, no significant differences were detected in experimental treatments supplemented with 0,75 and $150 \mathrm{mg}$ propolis $/ \mathrm{kg}$. It could be observed that thymus, the percentage of follicular cortex increased in a dose-dependent manner of proplis. This means that there are histological modifications in bursa of fabricius and thymus due to propolis supplementation in growing Japanese quail. These results are in harmony with the results shown in Table (3) and confirmed that bursa of fabricius and thymus were more developed due to dietary propolis supplementation in growing Japanese quail which, in turn, translated into elevating the absolute and relative weights of them (Table 3). It could be assume that, from histometrical examination, $300 \mathrm{mg}$ propolis improves follicular size in bursa and follicular cortex in thymus that reflect on level of lymphopiosis occur in this area and increase cellular immunity.

Table 7. Effect of propolis supplementation on histometrical parameters in bursa of fabricius and thymus of Japanese quail at 6 weeks of age

\begin{tabular}{|c|c|c|c|c|c|c|}
\hline \multirow[b]{2}{*}{ Items } & \multicolumn{6}{|c|}{ Dietary treatments* } \\
\hline & $\mathrm{T} 1$ & $\mathrm{~T} 2$ & $\mathrm{~T} 3$ & $\mathrm{~T} 4$ & T5 & $\begin{array}{c}\mathrm{P} \\
\text { value }\end{array}$ \\
\hline \multicolumn{7}{|l|}{ Bursa of fabricius: } \\
\hline Total follicle $(4 \mathrm{x})$ & $33.67 \pm 2.60^{\mathrm{a}}$ & $36.00 \pm 1.73^{\mathrm{a}}$ & $32.33 \pm 2.19^{\mathrm{ab}}$ & $27.33 \pm 1.45^{\mathrm{bc}}$ & $23.67 \pm 0.88^{c}$ & 0.005 \\
\hline Large follicle $(4 \mathrm{x})$ & $15.33 \pm 1.76$ & $16.67 \pm 0.88$ & $14.67 \pm 0.88$ & $13.00 \pm 1.00$ & $12.33 \pm 1.20$ & 0.147 \\
\hline Small follicle $(4 \mathrm{x})$ & $18.33 \pm 0.88^{\mathrm{a}}$ & $19.33 \pm 0.88^{\mathrm{a}}$ & $17.67 \pm 1.45^{\mathrm{a}}$ & $14.33 \pm 0.67^{\mathrm{b}}$ & $11.33 \pm 0.67^{\mathrm{b}}$ & 0.001 \\
\hline Diameter of large follicle $(10 \mathrm{x})$ & $371.33 \pm 11.41^{\mathrm{c}}$ & $363.67 \pm 4.91^{\mathrm{c}}$ & $362.67 \pm 12.57^{\mathrm{c}}$ & $407.67 \pm 6.49^{\mathrm{a}}$ & $425.00 \pm 3.61^{\mathrm{a}}$ & 0.001 \\
\hline Diameter of small follicle (10x) & $151.33 \pm 8.76^{\mathrm{c}}$ & $140.67 \pm 2.96^{\mathrm{c}}$ & $145.67 \pm 4.91^{\mathrm{c}}$ & $184.67 \pm 3.53^{\mathrm{b}}$ & $212.67 \pm 2.03^{\mathrm{a}}$ & 0.001 \\
\hline \multicolumn{7}{|l|}{ Thymus: } \\
\hline$\overline{\text { Percentage of follicular cortex }(\%)}$ & $63.00 \pm 63.00^{c}$ & $64.67 \pm 64.67^{\mathrm{c}}$ & $67.33 \pm 67.33^{\mathrm{bc}}$ & $73.33 \pm 73.33^{\mathrm{b}}$ & $82.33 \pm 82.33^{\mathrm{a}}$ & 0.001 \\
\hline
\end{tabular}

In fact, bursa of fabricius and the thymus are "central lymphoid organs" in poultry, and are essential to the ontogenetic development of adaptive immunity in birds. The T- and B-cell concept entered the vocabulary of immunology only after basic research with the chicken model revealed an immunological role for the bursa of fabricius (Warner et al., 1962 and Cooper et al., 1966) and the avian thymus (Cooper et al., 1966) which involved in regulating the humoral- and cellular- mediated immunity.

Data obtained from this study indicated that propolis at $300 \mathrm{mg} / \mathrm{kg}$ diet may exert beneficial effects on performance, blood hematology and constituents, immunity and anti-oxidative properties of growing Japanese quail. 


\section{REFERANCES}

Abbas, Amany A., M. M. El-Asely, Amel and M. M. Kandiel, 2012. Effects of Dietary Propolis and Pollen on Growth Performance, Fecundity and Some Hematological Parameters of Oreochromis niloticus. Turkish Journal of Fisheries and Aquatic Sciences, 12: 851-859.

Abd El-Fattah, A. M., E. M. Mohamed, E. Mohamed and G. Ramadan, 1999. Effect of thymus extract on immunologic reactivity of chicken vaccinated with infectious bursal disease virus. Journal of Veterinary Medical Science, 61: 811-817.

Abdel-Rahman, M. A. and G.M. Mosaad, 2013. Effect of propolis as additive on some behavioural patterns, performance and blood parameters in Muscovy broiler ducks. Journal of Advanced Veterinary Research, 3: 64-68.

Acikgoz, Z., B. Yucel and O. Altan, 2005. The effects of propolis supplementation on broiler performance and feed digestibility. Archiv Für Geflügelkunde, 69: 117-122.

Amal F., 1997. Pharmacological studies on Nigella sativa L on chickens infected with Salmonella typhimurium, M.S. thesis, Faculty of Veterinary Medicine, Zagazig University, Zagazig, Egypt.

Ansorge, S., D. Reinhold and U. Lendeckel, 2003. "Propolis and some of its constituents downregulate DNA synthesis and inflammatory cytokine production but in duce TGF- $\beta 1$ production of human immune cells," Zeitschrift fur Naturforschung C, 58(7-8): 580-589.

Babaei, S., S. Rahimi, M. A. KarimiTorshizi, N. KhaleghiMiran, G. A. Nehzati and N. Razmgah, 2004. Effects of propolis, honey, royal jelly, and bee pollen on the growth performance and blood parameters of quail (Coturnixcoturnix japonica). Poultry Science, (E-suppl.1): 389 P.

Banskota, A. H., Y. Tezuka and S. Kadota, 2001. Recent progress in pharmacological research of propolis. Phytotherapy Research, 15: 561-571.

Burdock, G. A., 1998. Review of the biological properties and toxicity of bee propolis (Propolis). Food and Chemical Toxicology, 36: 347-363.

Canogullari, S., M. Baylan, N. Sahinler and A. Sahin, 2009. Effects of propolis and pollen supplementations on growth performance and body components of Japanese quails (Coturnix coturnix japonica). Arch. Geflügelk., 73: 173-178.

Çetin, E., M. Kanbur, S. Silicim and G. and Eraslan, 2010a. Propetamphos- induced changes in haematological and biochemical parameters of female rats: protective role of propolis. Food and Chemistry Toxicity, 48: 1806-1810.

Çetin, E., S. Silici, N. Çetin and B. K. Güçlü, 2010 b. Effects of diets containing different concentrations of propolis on hematological and immunological variables in laying hens. Poultry Science, 89: 1703-1708.

Chu, W. H., 2006. Adjuvant effect of propolis on immunization by inactivated Aeromonas hydrophila in carp (Carassrus auratus gibelio). Fish \& Shellfish Immunology, 21: 113-117.

Cooper, M. D., R. D. Peterson, M. A. South and R. A. Good, 1966. The functions of the thymus system and bursa system in the chicken. The Journal of Experimental Medicine, 123: 75-106.

Culling, C. F., 1983. Handbook of Histopathological and Histochemical Staining Techniques. ${ }^{\text {rd }}$ Ed.; Butterworth - London.

Daneshmand, A., G. H. Sadeghi and A. Karimi, 2012. The effects of a combination of garlic, oyster mushroom and propolis extract in comparison to antibiotic on growth performance, some blood parameters and nutrients digestibility of male broiler. British Journal of Poultry Science, 14: 141-147.

Daneshmand, A., G. H.Sadeghi, A. Karimi, A. Vaziry and S. A. Ibrahim, 2015. Evaluating complementary effects of ethanol extract of propolis with the probiotic on growth performance, immune response and serum metabolites in male broiler chickens. Livestock Science, 178: 195-201.

Denli, M., F. Okan and A. N. Uluocak, 2004. Effect of dietary supplementation of herb essential oils on the growth performance, carcass and intestinal characteristics of quail (Coturnix coturnix japonica). South African Journal of Animal Science, 34: 79-85.

Denli, M., S. Cankaya, S. Silici, F. Okan and A. N. Uluocak, 2005. Effect of dietary addition of Turkish propolis on the growth performance, carcass characteristics and serum variables of quail. Asian-Australian Journal Animal Science, 18: 848-854.

Dimov, V., N. Ivanovska, V. Bankova and S. Popov, 1992. Immunomodulatory action of propolis: IV. Prophylactic activity against gram-negative infections and adjuvant effect of the water-soluble derivative. Vaccine, 10: 817-823.

Dobrowolski, J. W., S. B. Vohora, K. Sharma, S. A. Shah, S. A. Naqvi and P. C. Dandiya, 1991. Antibacterial, antifungal, antiamoebic, antiinflammatory and antipyretic studies on propolis bee products. Journal of Ethanopharmacology, 35: $77-82$.

Duncan, D. B., 1955. The multiple range and F-tests. Biometrics, 11: 1-42.

El-Hanoun, A. M., H. A. El-Saieed, M. S. El-Sbeiy and K. I. Kamel, 2007a. Effect of bee pollen supplementation on some productive, reproductive and biochemical traits of growing male rabbits during winter and summer seasons. $5^{\text {th }}$ inter. Conf. on Rabbit Prod. in Hot Clim., 4-7 Dec., Hurghada, Egypt. 417-433.

Elmahdi, B., S.M. El-Bahr and A. M. Abdelghany, 2014. Effect of dietary supplementation of Fenugreek (Trigonella foenum-graecum L.) on selected biochemical parameters of rats fed high cholesterol diet: Profiles of lipid and lipoproteins. SYLWAN, 158: 399-420. 
Freitas, S. F., L. Shinohara, J. M. Sforcin and S. Guimarães, 2006. In vitro effects of propolis on Giardia duodenalis trophozoites. Phytomedicine, 13: 170-175.

Fuliang, H .U., H. R. Hepburn and H. Xuan, 2005. Effects of propolis on blood glucose, blood lipid and free radicals in rats with Diabetes mellitus. Pharmacology Research, 51: 147-152.

Galal, A., A. M. AbdEl-Motaal, A. M. H. Ahmed and T. G. Zaki, 2008. Productive performance and immune response of laying hens as affected by dietary propolis supplementaion. Inter. Journal of Poultry Science, 7: 272-278.

Gekker, G., S. Hu, M. Spivak, J. R. Lokensgard and P. K. Peterson, 2005. Anti-HIV-1 activity of propolis in CD4 (+) lymphocyte and microglial cell cultures. Journal of Ethanopharmcology, 102: 158-163.

Haro, A., I. Lopez-Aliaga, F. Lisbona, M. Barrionuevo, M. J. Alferez and M. S. Campos, 2000. Beneficial effect of pollen and/or propolis on the metabolism of iron, calcium, phosphorus and magnesium in rats with nutritional ferropenic anemia. Journal of Agricultural and Food Chemistry, 48: 5715-5722.

Hawk, P. B., B. L. Oscar and W. Summerson, 1965. Hawk's [physiological chemistry]. London J., and A. Churchill Ltd. $14^{\text {th }}$ Ed.

Hegazi, A. G., H. F. El Miniawy and F. A. El Miniawy, 1995. Effect of some honeybee products on immune response of chicken infected with Virulent NDV. Egyptian. Journal of Immunology, 2: 79-86.

Hegazi, A., A. M. Abdou, and Fyrouz, Abd Allah, 2012. Egyptian Propolis 9- Its Effect on Chicken Productivity and Immune Response Against Newcastle Disease Vaccine. British Journal of Poultry Science, 1: 25-30.

Hegazi A. E., F. A. El Miniawy and F. K. Abd EL Hady, 1996. Influence of adminstration of propolis on chicken imunne status. The Egypt. Journal of Immunology, 3: 111- 116.

Jasprica, I., A. Mornar, Z. Debeljak, A. S. Bubalo, M. M. Saric, L. Mayer, Z. Romic, K. Bucan, T. Bagol, S. Sobocanec, S. and V. Sverko, 2007. In vivo study of propolis supplementation effects on antioxidative statuse and red blood cells. Journal of Ethnopharmacology, 110: 548-554.

Jeonm, S. M., S. H. Bok, M. K. Jang, Y. H. Kim K. T. Nam, T. S. Jeong, Y. B. Park and M. S. Choi, 2002. Clinica Chimica Acta, 317: 181-190.

Kamel, K. I., A. M. El-Hanoun, M. S. El-Sbeiy and H. A. M. Gad, 2007. Effect of bee propolis extract (bee glue) on some productive, reproductive and physiological traits of rabbits does and their progenys. The $5^{\text {th }}$ International Conference On Rabbit Production in Hot Climate, Hurghada, Egypt, 403-415.

Kawahara, E., T. Ueda and S. Nomura, 1991. In vitro phagocytic activity of white-spotted shark cells after injection with Aermonas salmonicida extracellular products. Gyobyo Kenkyu, Japan, 26: 213-214.

Khalil, F. A. and N. M. El-Sheikh, 2010. The Effects of Dietary Egyptian Propolis and Bee Pollen Supplementation against Toxicity if Sodium Fluoride in Rats. Journal of American Science, 6: 310-316.

Kimoto, T., S. Arai, and M. Kohguchi, 1998. Apoptosis and suppression of tumor growth by artepillin C extracted from Brazilian propolis. Cancer Detection and Prevention, 22(6): 506-515.

Kleczek, K., Wawro, E., Wawro, K., Makowski, W., Murawska, D. and Wawro, M. (2014). The effect of dietary propolis supplementation on the growth performance of broiler chickens. Polish Journal of Natural Sciences, 29(2): 105-117.

Kolankaya, D., G. Selmano glu, K. Sorkun and B. Salih, 2002. Protective effects of Turkish propolis on alcohol-induced serum lipid changes and liver injury in male rats. Food Chemistry, 78(2): 213217.

Krol, W., Z. Czuba, S. Scheller, J. Gabrys, S. Grabiec and J. Shani, 1990. Antioxidant property of ethanolic extract of propolis (EEP) as evaluated by inhibiting the chemiluminescence oxidation of huminal. Bioch. Inter., 21: 593-597.

Lee, S. W., H. J. Kim and S. Hwangbo, 2001. Studies on the chemical characteristic of Korean propolis. Journal of Korean Society For Food Science of Animal Research, 21: 383-388.

Mahmoud, U. T., M. A. Abdel-Rahman and Madeha Darwish, 2013. The Effect of Chinese Propolis Supplementation on Ross Broiler Performance and Carcass Characteristics. Journal of Advanced Veterinary Research, 3: 154-160.

Marcucci, M. C., 1995. Propolis: chemical composition, biological properties and therapeutic activity. Apidologie, 26: 83-99.

Molina, M. F., I. Sanchez-Reus, I. Iglesias and J. Benedi, 2003. Quercetin, a flavonoid antioxidant, prevents and protects against ethanol-induced oxidative stress in mouse liver. Biological and Pharmaceutical Bulletin, 26(10):1398-1402.

Nagyova, A., S. Galbavy and E. Ginter, 1994. Histopathological evidence of vitamin $\mathrm{C}$ protection against $\mathrm{Cd}$-nephrotoxicity in guinea pigs. Experimental and Toxicologic Pathology, 46: $11-14$

Nakamura, R., R. Nakamura., K. Watanabe, K. Oka, S. Ohta, S. Mishima and R. Teshima, 2010. Effects of propolis from different areas on mast cell degranulation and identification of the effective components in propolis. International Immunopharmacology, 10: 1107-1112.

National Research Counsil (NRC), 1994. Nutritional requirements of Poultry. Ninth revised edition, National press Washington. D. C

Orsi, R. O., J. M. Sforcin, S. R. C. Funari, Jr. A. Fernandes and V. Bankova, 2006. synergistic effect of propolis and antibiotics on Sallmonella typhi. Brazilian Journal of Microbiology, 37: 108112. 
Orsolic, N. and I. Basic, 2003. Immuno-modulation by watersoluble derivatives of propolis: a factor of anti-tumour reactivity. Journal of Ethnopharmacology, 84(2-3) 265-273.

Orsolic, N. I. and Basic, 2005. Water-soluble derivative of propolis and its polyphenolic compounds enhance tumoricidal activity of macrophages. Journal of Ethnopharmacology, 102:37-45.

Osman M. F. and E. A. Taha, 2008. Antioxidant activity of water extract of propolis from different regions in Kafrelsheikh Governorate. Alexandria Journal of Food Science \& Technology, 1: 83-89.

Popova, M., R. Dimitrova, H. T. Al-Lawati, I. Tsvetkova, H. Najdenski and V. Bankova, 2013. Omani propolis: chemical profiling, antibacterial activity and new propolis plant sources. Chemistry Central Journal, 7: 158-166.

Russo, A., R. Acquaviva, A. Campisi, V. Sorrenti, C. Di Giacomo, G. Virgata, M. L. Barcellona and A. Vanella, 2000. Bioflavonoids as antiradicals, antioxidants and DNA cleavage protectors. Cell Biology and Toxicology, 16: 91-98.

Sahin, A., M. Baylan, S. Sahinler, S. Canogullari and A. Gul, 2003. The effects of propolis on fattening performance and slaughter traits of Japanese quail. Marmara Beekeeping Congress Proceedings, April 28-30, Yalova Turkey.

Scazzochio, F., F. D. Dauria, D. Alessandrini and F. Pantanella, 2006. Multifactorial aspects of antimicrobial activity of propolis. Microbiological Research, 161: 327-333.

Seo, K. W., M. Park, Y. J. Song, S. J. Kim and K. R. Yoon, 2003. The protective effects of Propolis on hepatic injury and its mechanism. Phytother Research, 17: 250-253.

Sforcin, J. M., A. F. Júnior, C. Lopes, V. Bankova and S. Funari, 2000. Seasonal effect on Brazilian propolis antibacterial activity. Journal of Ethnopharmacoogy, 173: 243-249.

Sforcin, J. M., J. A. Fernandes, C. A. M. Lopes, S. R. C. Funari and V. Bankova, 2001. Seasonal effect of Brazilian propolis on Candida albicans and Candida tropicalis. Journal of Venomous Animals and Toxins, 7: 139-144.
Shalmany, S. and M. Shivazad, 2006. The effect of diet propolis supplementation on ross broiler chicks performance. International Journal of Poultry Science, 5: 84-88.

Shawky, T., 1996. The immuno-potentiating Impact of zinc and Vit. E in buffalo calves, Master thesis, Cairo University, Giza, Egypt.

Silici, S., M. Uenlue and G. Vardar-Uenlue, 2007. Antibacterial activity and phytochemical evidence for the plant origin of Turkish propolis from different regions. World Journal of Microbiology \& Biotechnology, New York, 23: 1797-1803.

Snedecor, W. and W. Cochran, 1980. Statistical methods. Iowa State University Press, Ames Iowa, seventh edition.

Song, Y. S., C. B. Jin, K. J. Jung and E. H. Park, 2002. Estrogenic effects of ethanol and ether extracts of propolis. Journal of Ethnopharmacology, 82: 89-95.

SPSS, 2007. SPSS for Windows Release 16.0, SPSS .Inc.

Tatli Seven, P., S. Yılmaz, I. Seven, I. H. Çerçi, M. A. Azman and M. Y1lmaz, 2009. The effect of propolis on selected blood indicators and antioxidant enzyme activities in broilers under heat stress. Acta Vet Brno, 78: 75-83.

Tekeli, A., H. R. Kutlu and L. Celik, 2011. Effects of Z. officinale and propolis extracts on the performance, carcass and some blood parameters of broiler chicks. Current Research in Poultry Science, (1):12-23.

Vatansever, H. S., K. Sorkun, S. I. Gurhan, F. OzdalKurt, E. Turkoz, O. Gencay and B. Salih, 2010. Propolis from Turkey induces apoptosis through activating caspases in human breast carcinoma cell lines. Acta Histochemica, 112: 546-556.

Warner, N. L., A. J. Szenberg and F. M. Burnet, 1962. The immunological role of different lymphoid organs in the chicken. I. Dissociation of immunological responsiveness. The Australian journal of experimental biology and medical science, 40: 373-388. 


\section{تأثير إضافة البروبوليس على الأداء الانتاجي والمقاييس المناعية والفسيولوجية فى السمان الياباني النامي وليد مصطفى دسوقى'، حسن صابر زويل'، سهى عبد الحميد فرج'}

ا قسم الانتاج الحيوانسي والسمكي، كلية النراعة سابا باثا، جامعة الاسكندرية، ب ـقسم الانتاج الحيوانسي، كلية الزراعة، جامعة طنطا

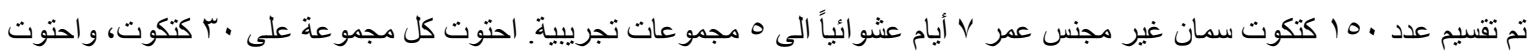

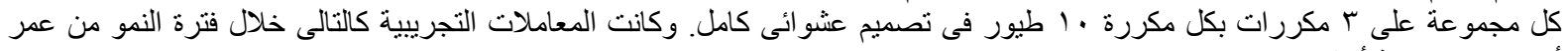
أسبوع وحتى ستة أسابيع.

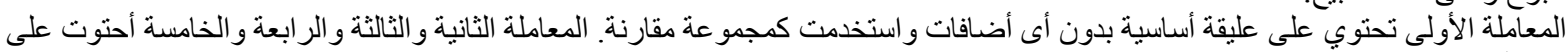

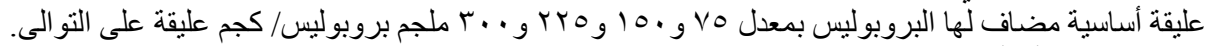

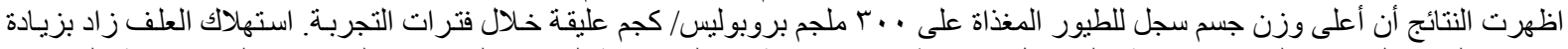

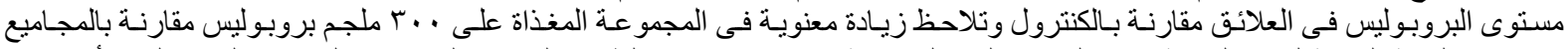

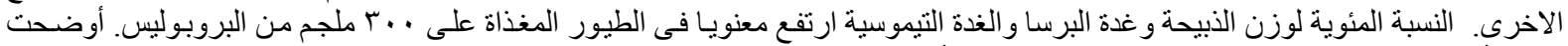

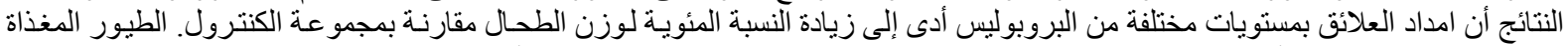

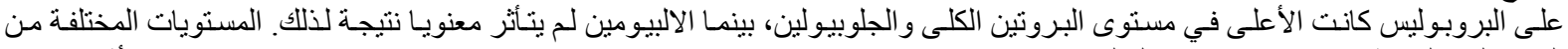

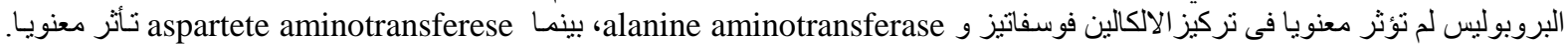

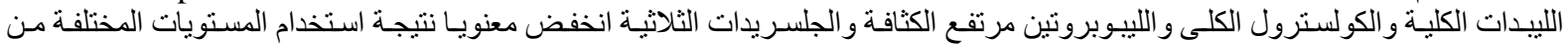

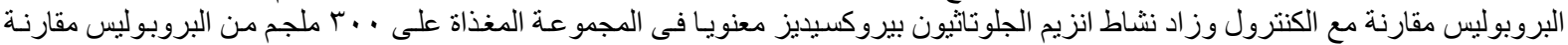

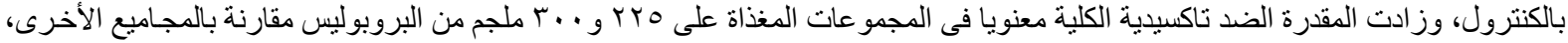

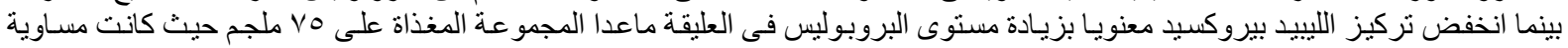

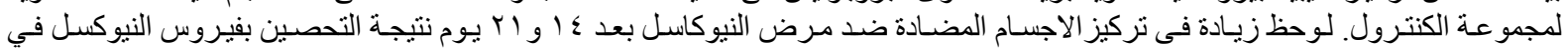

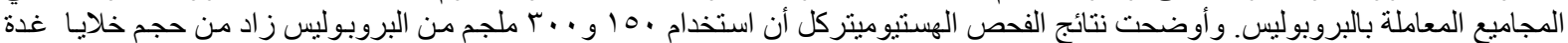
البرسا و الغدة التيموسية.

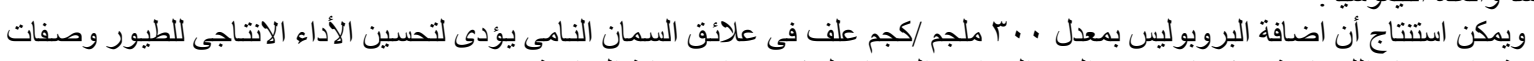

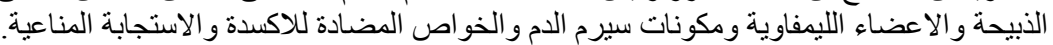

